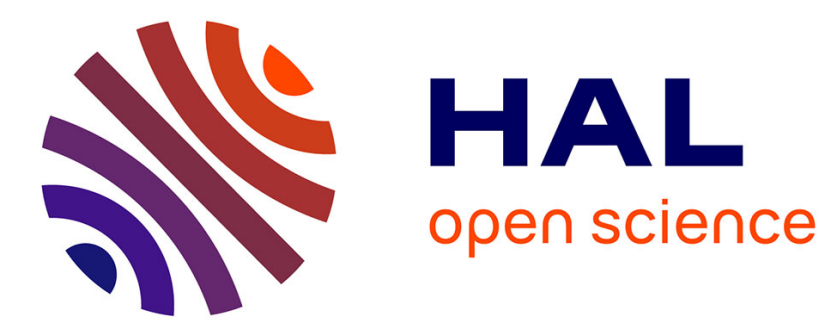

\title{
Rayleigh scattering from pivalic acid
}

D. Beysens, R. Vacher, G.M. Searby, L. Boyer, M. Adam

\section{To cite this version:}

D. Beysens, R. Vacher, G.M. Searby, L. Boyer, M. Adam. Rayleigh scattering from pivalic acid. Revue de Physique Appliquée, 1974, 9 (2), pp.465-467. 10.1051/rphysap:0197400902046500 jpa-00243803

\section{HAL Id: jpa-00243803 https://hal.science/jpa-00243803}

Submitted on 1 Jan 1974

HAL is a multi-disciplinary open access archive for the deposit and dissemination of scientific research documents, whether they are published or not. The documents may come from teaching and research institutions in France or abroad, or from public or private research centers.
L'archive ouverte pluridisciplinaire HAL, est destinée au dépôt et à la diffusion de documents scientifiques de niveau recherche, publiés ou non, émanant des établissements d'enseignement et de recherche français ou étrangers, des laboratoires publics ou privés. 
Classification

Physics Abstracts

8.810

\title{
RAYLEIGH SCATTERING FROM PIVALIC ACID
}

\author{
D. BEYSENS, R. VACHER (*), G. M. SEARBY, L. BOYER (*) and M. ADAM
}

Service de Physique du Solide et de Résonance Magnétique Centre d'Etudes Nucléaires de Saclay, BP 2, 91190 Gif-sur-Yvette, France

(Reçu le 26 septembre 1973)

\begin{abstract}
Résumé. - Les spectres de diffusion Rayleigh polarisés et dépolarisés de l'acide pivalique ont été mesurés avec une grande précision. Le temps de relaxation de réorientation moléculaire et l'énergie d'activation sont déduits directement de ces mesures pour les phases plastiques et liquides du cristal.

Abstract. - Both the polarized and depolarized spectra of Rayleigh scattering from pivalic acid have been measured with high precision. The relaxation time for molecular reorientation and the energy of activation are deduced directly from these measurements for both the liquid and plastic phases of the crystal.
\end{abstract}

1. Introduction. - A high resolution study of the spectrum of light scattered quasi-elastically by succinonitrile [1], [2] has recently permitted us to observe scattering from fluctuations in anisotropy and from fluctuations in entropy in an ordered system. The combined spectrum $\sum$, shown in figure 1 , is the sum of three components. Spectrum (a) is depolarized and arises from fluctuations in anisotropy, these fluctuations have been attributed to the rotation of the nitrile group. The profile (s) is polarized and arises from

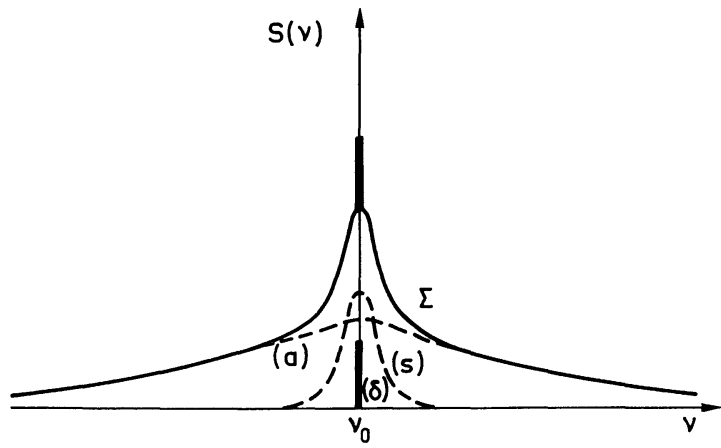

Fig. 1. - Typical spectrum of plastic crystals. The spectral density $S(v)$ is plotted against the frequency $v$ of the scattered light. $v_{0}$ is the frequency of the light source. The width of the line $(s)$ is always about $10 \mathrm{MHz}$ (backward scattering), whereas the width of the profile (a) is typically $10^{2}$ or $10^{3} \mathrm{MHz}$. $(\delta$ ) can be assimilated to a Dirac function.

(*) LPEC, Université des Sciences et Techniques du Languedoc, 34060 Montpellier, France. entropy fluctuations ; $(\delta)$, also polarized, is caused by elastic scattering from static imperfections. The widths of these lines are related to the relaxation time of the process responsible for the scattering.

This type of experiment thus allows us to obtain quantitative information about the rotational motion of radicals or molecules in plastic crystals, and also to measure the coefficient of thermal diffusivity.

The object of this paper is to present the results of similar investigations of pivalic acid $\left(\left(\mathrm{CH}_{3}\right)_{3} \mathrm{CO}_{2} \mathrm{H}\right)$. This substance exists in a plastic phase between the temperatures $7{ }^{\circ} \mathrm{C}$ and $37^{\circ} \mathrm{C}$.

The molecules, which are globular in shape, occupy the sites of a face centered cubic lattice. Dielectric measurements [3] have shown that the molecules are coupled by hydrogen bonds to form dimers. Rupture of the hydrogen bond permits the reorientation of the molecule along any of the twelve equiprobable directions. The fluctuations in anisotropy are thus related to a step-like rotation of the whole molecule [4].

The depolarized spectrum was first observed by Bird et al. [5]. In this present work we study the complete Rayleigh spectrum with a higher spectral resolution.

2. Polarized scattering : measurement of the coefficient of thermal diffusivity. - The light scattered by entropy fluctuations is polarized. The profile of the spectrum has lorentzian shape of half-width $\Gamma_{\mathrm{s}}$, where : $\Gamma_{\mathrm{s}}=D K^{2}, \mathrm{D}$ is the thermal diffusion coefficient and

$$
K=\frac{4 \pi n}{\lambda} \sin \frac{\theta}{2}
$$


$\theta$ is the scattering angle in the medium, $\lambda$ the wavelength of the incident light and $n$ the refractive index.

The spectrum was analysed using an optical heterodyne technique at small forward angles $\left(40^{\prime}<\theta<1^{\circ} 35^{\prime}\right)$. The experimental apparatus has already been described in a previous paper [2]. The sample is a single crystal of excellent optical quality. It was grown in a sealed cell by $\mathrm{H}$. Fontaine (*) using a Bridgmann-Stockbarger technique.

Figure 2 shows the dependence of $\Gamma_{\mathrm{s}}$ on $K^{2}$. We find :

$$
D=(6.7 \mp 1) 10^{-4} \mathrm{~cm}^{2} \mathrm{~s}^{-1} \text {. }
$$

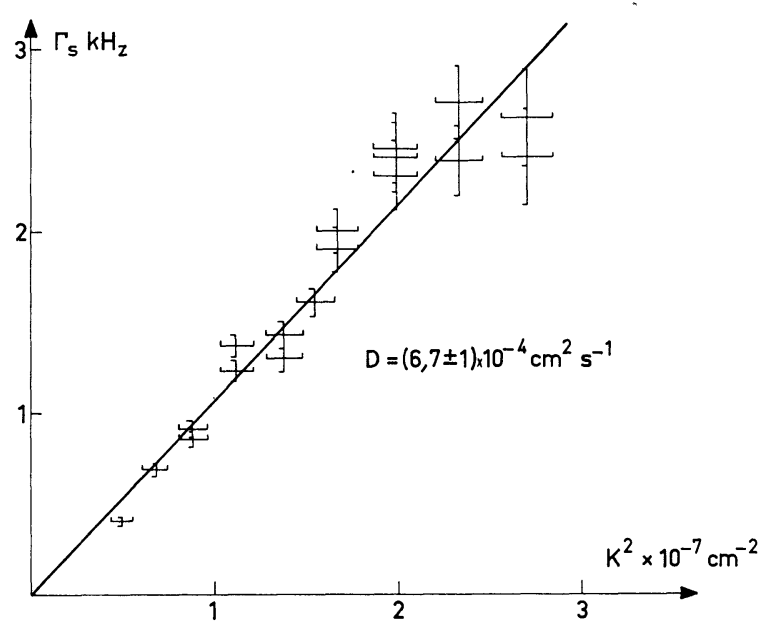

FIG. 2. - Variation of $\Gamma_{\dot{s}}$ vs $K^{2}$ at room temperature.

3. Depolarized scattering : studies of molecular motion. - The scattering arising from fluctuations in anisotropy is depolarized and the width of the spectrum does not depend on the scattering angle. These properties permit us to distinguish it from the spectrum caused by entropy fluctuations.

In the plastic phase, the half-width of the depolarized spectrum is typically $20 \mathrm{MHz}$ and was analysed by means of a spherical Fabry-Perot interferometer whose free spectral range was $213 \mathrm{MHz}$ and instrumental half-width $2.1 \mathrm{MHz}$ [6]. Fitting and deconvolution by computer of the experimental data enabled us to calculate the Rayleigh coefficient and half width $\Gamma_{\mathrm{a}}$ of the spectrum (Fig. 3a).

Measurements in the liquid phase were continued using plane Fabry-Perot interferometers with spacings of 5 and $2.5 \mathrm{~mm}$. The instrumental half-widths were 0.25 and $0.63 \mathrm{GHz}$ respectively. Figure $3 b$ shows a spectrum recorded at $50^{\circ} \mathrm{C}$.

The ratio of the depolarized Rayleigh coefficient $\boldsymbol{R}_{\boldsymbol{\theta}}$ for pivalic acid to the (polarized) coefficient for benzene at $20^{\circ} \mathrm{C}$ was measured in the temperature interval

(*) Laboratoire de Physique du Solide. Rayons X, Université des Sciences et Techniques de Lille, BP 36, 59-Villeneuve-d'Asq, France.
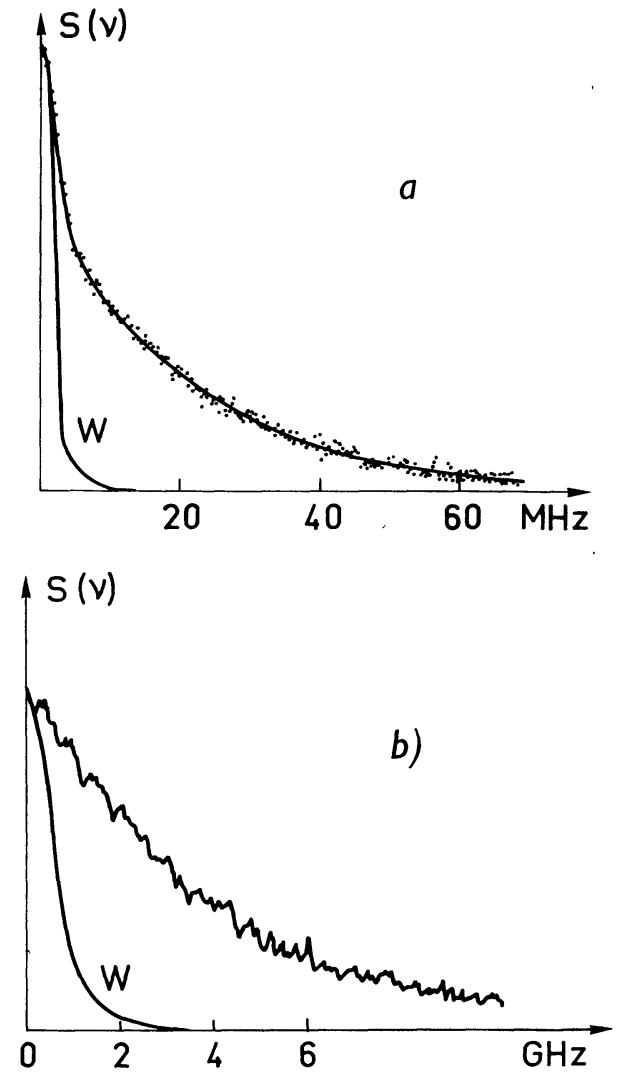

FIG. 3. - a) Spectrum obtained at $36^{\circ} \mathrm{C}$ using the spherical interferometer. b) Spectrum obtained at $50{ }^{\circ} \mathrm{C}$ with a plane Fabry-Perot interferometer. In both cases the apparatus function $W$ has been recorded.

$8^{\circ} \mathrm{C}$ to $36^{\circ} \mathrm{C}$. This ratio is roughly independent of temperature within experimental precision. We obtain

$$
\frac{R_{\theta} \text { piv }}{R b z}=0.21 \mp 0.05 \text {. }
$$

The reorientation time $\tau_{\mathrm{a}}$, deduced from the measurements of $\Gamma_{\mathrm{a}}\left(\tau_{\mathrm{a}}=1 / 2 \pi \Gamma_{\mathrm{a}}\right)$ is plotted as a function of temperature in figure 4 . The reorientation time follows an Arrhenius-type law with activation energy :

$$
\begin{aligned}
& 0.32 \mp 0.04 \mathrm{eV} \text { in plastic phase } \\
& 0.16 \mp 0.01 \mathrm{eV} \text { in liquid phase }
\end{aligned}
$$

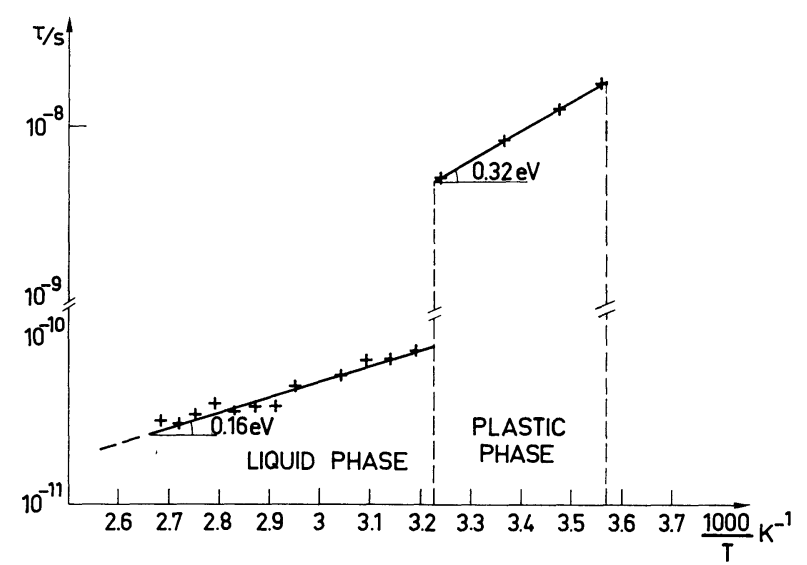

FIG. 4. - Relaxation time as a function of temperature. 
4. Conclusion. - Our experiments have enabled us to measure directly the activation energy and the relaxation time of the rotational movements in pivalic acid.

In the liquid phase the reorientation time $\left(10^{-10} \mathrm{~s}\right)$ is much greater than in a non-associated liquid with an equivalent molecular weight $\left(10^{-12} \mathrm{~s}\right)$ [7]. We may conclude therefore that even in the liquid state the molecules are associated by hydrogen-bonding.

It is interesting to compare the results of measurements made in the plastic phase with the values deduced indirectly from measurements made by NMR [4] and radio-active tracer techniques [4]

(Table I). The excellent agreement between the three sets of values confirms the description of the crystal which was presented in the introduction.

\begin{tabular}{|c|c|c|c|}
\hline Type of measurement & $E(\mathrm{eV})$ & $\begin{array}{c}\tau\left(\times 10^{8} \mathrm{~s}\right) \\
\text { at } 286 \mathrm{~K}\end{array}$ & Ref. \\
\hline NMR & $0.37 \pm 0.04$ & 1.0 & $\begin{array}{l}\text { Jackson- } \\
\text { Strange [4] }\end{array}$ \\
\hline Radio-active tracer & 0.39 & 1.3 & id. \\
\hline Light scattering & $\begin{array}{l}0.32 \pm 0.04 \\
0.62 \pm 0.08\end{array}$ & $\begin{array}{l}1.3 \\
3.2\end{array}$ & $\begin{array}{c}\text { Our result } \\
\text { Bird et al. } \\
\text { [5] }\end{array}$ \\
\hline
\end{tabular}

\section{References}

[1] Boyer, L., VACher, R., Cecchi, L., Adam, M. and Bergé, P., Phys. Rev. Lett. 26 (1971) 1435.

[2] Adam, M., Searby, G. and Bergé, P., Phys. Rev. Lett. 28 (1972) 228.

[3] Kondo, S. and OdA, T., Bull. Chem. Soc. Japan 27 (1954) 567.

[4] Jackson, R. L. and Strange, J. H., Mol. Phys. 22 (1971) 313.
[5] Bird, M. J., JaCkson, D. A. and Powles, J. G., VII International Quantum Flectronics Conference in Montreal (May 1972).

[6] Beysens, D., Revue Phys. Appl. 8 (1973) 175.

[7] Pinnow, D. A., Candau, S. J. and Litovitz, T. A., J. Chem. Phys. 49 (1968) 347. 